\title{
Altman's Bankruptcy Prediction Model: Test on a Wide Out of Business Private Companies Sample
}

\section{Mauricio Takahashi, Fernando Henrique Taques, Leonardo Basso}

Programa de Pós-Graduação em Administração de Empresas (PPGA), Mackenzie Presbiterian University, São Paulo, Brazil Email: prof.mauricio.takahashi@gmail.com,fernandohtaques@gmail.com, leonardofernando.basso@mackenzie.br

How to cite this paper: Takahashi, $M$; Taques, F.H. and Basso, L. (2018) Altman's Bankruptcy Prediction Model: Test on a Wide Out of Business Private Companies Sample. iBusiness, 10, 21-39. https://doi.org/10.4236/ib.2018.101002

Received: March 2, 2018

Accepted: March 24, 2018

Published: March 27, 2018

Copyright (c) 2018 by authors and Scientific Research Publishing Inc. This work is licensed under the Creative Commons Attribution International License (CC BY 4.0).

http://creativecommons.org/licenses/by/4.0/

\section{cc) (i) Open Access}

\begin{abstract}
This study tests the accuracy of the Altman bankruptcy prediction model for a wide private companies' sample that went bankrupt in the years 1985 to 2013. Financial ratios used in the model calculations, Z'-Score (Altman's Z for private companies) also provide useful information on the solvency and probability of bankruptcy for privately held companies from the sample. The findings do not support the assertion that the Z'-Score can be generalized to countries and sectors different from industrial sector. The general number of bankruptcies may be an antecedent variable to certain economic and/or financial crises, but the results indicate a correct identification of bankruptcy risk only to two thirds of the sample of companies.
\end{abstract}

\section{Keywords}

Z'-Score, Private Companies, Bankruptcy

\section{Introduction}

The economic literature suggests that business activity is closely linked to the process of uncertainty. In this case, organizations, irrespective of the nature of their activity, may go through certain financial difficulties, even in periods that are not characterized by financial instabilities.

[1] addressed the issue of corporate bankruptcy as an important phenomenon, because it compromises the financial performance and the continuity of business activity. Therefore, they stress that it is of interest to identify a possible signaling of this scenario, so that it is possible to decide with the purpose of reversing adversity and properly structuring the organization with the aim of reducing the possibility of bankruptcy. A seminal contribution on the subject was made by 
[2], with the aim of evaluating the prediction of bankruptcies of industrial companies through financial and accounting information, based on the multiple discriminant analysis technique. To do so, the author developed a set of ratios that generated higher explanation power for this issue.

[3] pointed out that indicators of profitability, liquidity and solvency are relevant in a univariate analysis. However, in a univariate system, the order of importance among the indicators is not clear in the empirical literature; therefore, it is important to consider a combination of prediction measures for a better understanding of the issue.

Accordingly, it is in the interest of organizations to observe the validity of indicators capable of indicating a situation of bankruptcy of companies aimed at promoting changes, whether structural or managerial. On the other hand, public policy makers can appropriate this information to predict adverse scenarios and to carry out alternatives that mitigate this effect, since this context implies effects on the real economy, primarily on employment and income.

Thus, the main objective of this research is to test the validity of the Z'-Score proposed by [4], the focus of which consists of an understanding of the dynamics of solvency for private (i.e., closely-held) companies. For such, it is based on the multiple discriminant analysis with the respective weights determined by the author, from a sample with a set of 622 companies, represented by several segments and countries, derived from Capital IQ ${ }^{\circledR}$ between 1985 and 2013.

The main contribution of the study is to test the validity of Altman's model [4], not only for industrial companies, but also for a set of data from more than ten countries and nine different sectors of economic activity. Validity provides a broader understanding, in such a way that financial and accounting instruments, when properly constructed, can extract information relevant to the proposed theme. It is also relevant to determine whether this model can provide an instrument to observe scenarios of financial and/or economic crises-a context that would allow effective actions such as reversion measures.

The paper is divided into three sections, beside introduction and conclusion. The first section describes the theoretical model of the Altman Z'-Score, the second one comprises an empirical review of the literature on such method, the third consists of the database and research method, and the last section presents the results and a discussion on the implications thereof.

\section{Corporate Bankruptcy}

[2] reveals that detection of a scenario of companies in financial difficulties has been of interest in the literature but understanding the phenomenon of bankruptcy requires measures of ratios of financial indicators. Until that time, the literature indicated that profitability, liquidity and solvency were the most representative indicators, but they encompassed a univariate understanding of the indicators, which raises questions about the validity of their generalizations, since companies have different relative performances. 
The author developed a multiple discriminant analysis (MDA) model, combining several measures into a single indicator. The method consists of classifying a result bound to a grouping of individual dependent characteristics of this observation, which is particularly useful for performing predictions with qualitative variables. Thus, the main advantage is associated with an entire profile of characteristics common to the firms and the interaction between such variables, while the univariate perspective makes use of one set of attributes at a time.

The model developed by [2] is part of a sample of 66 industrial companies, segmented into two groups of equal size, one of which went bankrupt and the other did not, during the period from 1946 to 1965. It is important to consider that the companies are not homogeneous, because they include differences in sector and in size, but all have assets between US\$ 1 million and US\$ 25 million.

By previous evidence, a list was formulated with 25 variables (indicators) for evaluation, whose data are extracted from the companies' balance sheet and income statement. Five categories of indicators were elaborated: a) liquidity, b) financial return, c) leverage, d) solvency, and e) activity. Thus, based on statistical criteria, it was observed that the most significant variables were not those used independently by the literature [2]. Hence, the discriminant function thereby obtained, called the Z-Score, is expressed as:

$$
Z=0.012 X_{1}+0.014 X_{2}+0.033 X_{3}+0.006 X_{4}+0.999 X_{5}
$$

In which:

$X_{1}$ : working capital/total assets

$X_{2}$ : retained earnings/total assets

$X_{3}$ : earnings before interest and taxes/total assets

$X_{4}$ : market value of equity/total liabilities

$X_{5}$ : sales/total assets

$Z: \mathrm{Z}$-Score (general ratio)

The possible results of the $\mathrm{Z}$-Score are presented in ranges, according to the following criteria:

1) $\mathrm{Z}$-Score $\leq 1.80$ : comprises the low performance range, i.e., bankrupt zone;

2) $1.81 \leq \mathrm{Z}$-Score $\leq 2.99$ : consists of the region of the gray zone, as it is susceptible to classification error;

3) Z-Score > 2.99: includes the area of companies with good financial performance, i.e., in healthy condition (non-bankrupt).

The results obtained by the author indicated that $94 \%$ of the companies of the sample were correctly identified, being this statistically significant result. [2] also considers that the results of the prediction model are accurate for up to two years before bankruptcy, although such accuracy diminishes with increasing analysis time, and considers applicability to be particularly useful for bankers, credit managers, executives and investors for decision making.

Subsequently, [4] constructed the Z'-Score model, specifically directed to closely-held industrial companies. Thus, the author revised the initial model of the Z-Score, substituting $X_{4}$ market value by the equity book value. Thus, the 
discriminant model becomes:

$$
\text { Z'Score }=0.717 X_{1}+0.0847 X_{2}+3.107 X_{3}+0.420 X_{4}+0.998 X_{5}
$$

The adaptation of the model, stemming from the fact that they are private companies, also demonstrates the importance of changing $X_{4}$. This adjustment allows a new classification criterion among the variables, so that the remaining variables $\left(X_{1}, X_{2}, X_{3}, X_{5}\right)$ continue to be relevant to understand the bankruptcy of companies [3] [5]. Because of this modification, the Z'-Score classification zones are:

1) Z'-Score < 1.23: Zone I (bankruptcy zone);

2) $1.23 \leq Z^{\prime}$-Score $\leq 2.90$ : gray zone;

3) Z'-Score> 2.90: Zone II (zone of companies classified as non-bankrupt).

The results obtained by the authors indicate accuracy close to the traditional Z-Score model. In this context, $91 \%$ of cases correctly identified failed firms (compared to $94 \%$ of the Z-Score) and $97 \%$ of the companies that did not fail were appropriately identified, as in the original model [3] [4] [5].

\section{Empirical Evidence}

Based on the seminal works of Altman, several authors made use of the methods with two primary objectives. The first one consists of validating the multiple discriminant model proposed by the author, while the second one seeks to make diagnoses and projections regarding the companies' results, i.e., it comprises a more practical character in the sense of applying the method for use in evaluating companies.

The first group of studies is particularly interesting for this paper, since it not only encompasses the discussion of the Z-Score and Z'-Score as a method, but also broadens the discussion by inserting issues of an economic, institutional and legal nature, as well as allowing to identify any possible applications and generalizations.

First, it should be noted that some works, such as that of [6], [8], and [9] have a small sample of companies. Such a condition limits the results to the scope of generalizations, and suggests that they should be observed with caution by the following factors: 1) the size of the company (small, medium or large) can be determinant in the result of the analysis; therefore, selecting a larger and heterogeneous sample allows for greater explanatory power; 2 ) the institutional nature of the country, such as policies for granting credit, bankruptcy laws and credit recovery laws, are instruments that can directly influence the result of termination of companies' activities; and 3) economic issues-such as expansionist fiscal or monetary policies-may be predominant in companies' financial results over a given period of time, as well as in their leverage, indebtedness and resilience in adverse scenarios and, likewise, liquidity in periods of expansion. Therefore, broader samples, sector segmentation, and identification of the size of the companies can bring more representative results to the method proposed by Altman. 
[7] and [9], in turn, have a study time limitation of less than three years. In the case of the last author, despite the representative sample, it only contemplates the collection of data for a single period. The issue of time is particularly relevant in problems of this nature, since there are mechanisms that can accelerate the process of bankruptcy of companies or even their recovery process. This is the case (at the macroeconomic level) of interest rates imposed on contracts, inflation, exchange rates and imposition of tax rates and/or tax benefits that can act directly on the companies' financial results. In the ambit of companies, the exchange of the debt profile (short/long term), intangible assets, and changes in the corporate scope may suggest a period of more than three years to reflect the value of the bankruptcy index, since this is guided by financial and accounting information.

The issue of time is also relevant in relation to the period of data collection. In other words, periods characterized by economic crises tend to generate greater adversity for companies and imply more highly representative results of the Z-Score and its variations in relation to the companies that went bankrupt. Extending the period of analysis with the aim of seeking a period with greater stability may represent a more competitive context in internal and external markets, which directly reflects the results of the companies and the chances of bankruptcy among them.

Accordingly, Table 1(a) shows a brief synthesis of some of the empirical evidence identified from the literature. The minority of the surveys indicated that the Z'-Score has consistent results for the reasons listed, including in comparison to the traditional Z-Score.

It is particularly important to note the argument raised by [9] regarding the accounting system of companies from different countries. The definition of a sample containing several countries can include different accounting systems and generate difficulties in the consolidation of accounting information, suggesting the possibility of divergent results in relation to the classifications defined by each country.

Similarly, [6] considers the importance of the level of development of the capital market. A more solid and consolidated market attracts more investor resources, not only to speculative capital but also to the real sector of the economy. Therefore, it allows for the expansion of the number of companies in the economy and increases the investment capacity of organizations.

\section{Methodology}

As the main objective of the paper is to test the accuracy of Altman's [4] model of prediction of bankruptcy for private companies, Z'-Score, the following hypotheses are proposed:

H1: The Z'-Score is valid for private companies, that is, it has representative explanatory power, as evidenced by [2] [4].

$\mathrm{H} 2$ : The Z'-Score is valid for companies from different countries. 
One of contributions of the research is to test the validity of the Altman model [4] not only for North American companies, but for several different countries.

H3: The Z'-Score is valid for companies in different sectors, that is, it is explanatory for forecasting bankruptcy for any segment of economic activity.

Another contribution of the research is to test the validity of Altman's model [4], not only for industrial companies, but for a set of nine different sectors of economic activity, including the financial sector.

H4: From the sample selected by the Z'-Score criterion, it is possible to identify some variable antecedent to economic and/or financial crises.

H5: Crises of an economic and/or financial nature also affect the target sectors of the study under the premise of selecting the Z'-Score sample.

For the accomplishment of the tests, the procedures of collection, selection, cleaning, classification and synthesis are executed for later analysis.

The first collection is done in the database of Capital IQ ${ }^{\circledast}$ with all the companies that have registered in this and subsequently failed (status: out of business). Table 1(b) shows the treatment evolution of the sample. The initial sample makes up 54,017 companies, and figures are found for the period between 1976 and 2015. A first selection of companies that have at least one value for the total assets is made, resulting in 3211 companies.

The second collection searches all other variables of the model for the 3211 companies of the first selection. Each Z'-Score factor is calculated considering the model for private companies (Z'-Score). Only the Z'-Score that has values in the five factors ( $X_{1}$ to $X_{5}$ ) are calculated per year per company, which results in 1561 companies.

Another criterion applied in the sample is the continuity of the Z'-Score for a period of five years or more for the same company. With this, it is possible to make a temporal analysis of the indicator and to identify the consistency of the results obtained by the Altman indicator. It is still a market practice for financial companies to adopt temporal analysis periods for financial analysis of their business customers.

Companies with four or fewer sequential periods and those with some Z'-Score discontinuity are excluded from the sample. The sample now contains 622 companies. For the period between 1970 and 1984, as well as between 2014 and 2015, there are no companies that meet these criteria. Therefore, the analysis covers the period between 1985 and 2013.

The sample stands out as a result of the significant number of companies, 622 . The number of years is also a highlight, since the period covered is between 1985 and 2013-that is, 29 years. The companies are classified by sectors based on the North America Industrial Classification (NAIC) and country of origin.

Segmentation seeks to provide a more detailed assessment of the specific characteristics inherent to the different sectors of economic activity, as well as recognizing that countries have distinct economic structures which affect the performance trajectory of companies. 
Table 1. (a) Empirical evidence; (b) Evolution of the treatment of the sample.

(a)

\begin{tabular}{|c|c|c|c|c|c|}
\hline Author(s) & Method & Sample & Period & Outcomes & Limitations \\
\hline [6] & $\begin{array}{c}\text { Z-Score and } \\
\text { Z'-Score }\end{array}$ & $\begin{array}{l}44 \text { private-sector } \\
\text { companies in } \\
\text { Serbia (Belgrade } \\
\text { Stock Exchange) }\end{array}$ & 2006-2009 & $\begin{array}{l}\text { There is no significant } \\
\text { difference between the } \\
\text { Z-Score calculation methods. } \\
\text { The results were not very } \\
\text { expressive, whose explanation } \\
\text { is directly linked to the local } \\
\text { characteristics, different } \\
\text { sectors, and the limited period }\end{array}$ & $\begin{array}{l}\text { Size of the sample available for the } \\
\text { capital market of Serbia. The } \\
\text { financial indicators of taxes on profit } \\
\text { were not published for some } \\
\text { companies, which reduces the power } \\
\text { of analysis. Moreover, the capital } \\
\text { market in Serbia does not reflect the } \\
\text { real value of the shares (it is an } \\
\text { incipient market that is of little } \\
\text { relevance in the country's economy) }\end{array}$ \\
\hline [7] & $\begin{array}{c}\text { Z-Score and } \\
\text { Z'-Score }\end{array}$ & $\begin{array}{l}477 \text { companies } \\
\text { located in } \\
\text { Malaysia } \\
\text { (eight industries) }\end{array}$ & May 31, 2010 & $\begin{array}{l}\text { The results of the calculated } \\
\text { models are significantly } \\
\text { different, with a smaller } \\
\text { number of companies in the } \\
\text { gray zone }\end{array}$ & $\begin{array}{l}\text { A single period of data collection limits } \\
\text { the analysis, mainly due to the } \\
\text { perception of investors about a more } \\
\text { liberal policy in the study period }\end{array}$ \\
\hline [8] & Z-Score & $\begin{array}{l}40 \text { Greek } \\
\text { companies listed } \\
\text { on the Hellenic } \\
\text { Stock Market } \\
\text { (Athexgroup) }\end{array}$ & 2006-2012 & $\begin{array}{l}\text { The model identified } 86 \% \text { of } \\
\text { the group of bankrupt } \\
\text { companies, but did not show } \\
\text { good performance for } \\
\text { companies that did not go } \\
\text { bankrupt ( } 18 \% \text { of prediction } \\
\text { appropriate) }\end{array}$ & $\begin{array}{l}\text { The period of economic instability in } \\
\text { Greece (persistent recession) affects } \\
\text { the data of companies with better } \\
\text { financial conditions and the most } \\
\text { vulnerable ones (corporate } \\
\text { indebtedness becomes much larger). } \\
\text { Additionally, the proportion of firms } \\
\text { in each segment is not equal }\end{array}$ \\
\hline [9] & Z'-Score & $\begin{array}{l}11 \text { manufacturing } \\
\text { companies in } \\
\text { Lebanon } \\
\text { (4 small/medium } \\
\text { and } 7 \text { large) }\end{array}$ & $2009-2011$ & $\begin{array}{l}\text { Z'-Score proved to be } \\
\text { accurate, including for the } \\
\text { classification of companies } \\
\text { regarding size }\end{array}$ & $\begin{array}{l}\text { Sample size, sample period are } \\
\text { constraints in the analysis. } \\
\text { Furthermore, Lebanese companies do } \\
\text { not follow the same accounting } \\
\text { regulations as US companies }\end{array}$ \\
\hline [10] & $\begin{array}{c}\text { Z-Score and } \\
\text { Z'-Score }\end{array}$ & $\begin{array}{l}44 \text { private-sector } \\
\text { companies in } \\
\text { Serbia (Belgrade } \\
\text { Stock Exchange) }\end{array}$ & $2006-2010$ & $\begin{array}{l}\text { Original Z-Score model } \\
\text { showed weak understanding, } \\
\text { but the Z'-Score indicated } \\
\text { more relevant results }\end{array}$ & $\begin{array}{l}\text { Specifics of the local economy may } \\
\text { reflect results, such as: low } \\
\text { competitiveness of companies vis-à-vis } \\
\text { other countries, chronic lack of } \\
\text { liquidity in the economy, and } \\
\text { exchange rate risk }\end{array}$ \\
\hline [11] & Z'-Score & $\begin{array}{l}399 \text { individual } \\
\text { farmers in Illinois } \\
\text { (USA) }\end{array}$ & $2000-2004$ & $\begin{array}{l}\text { The model presented } \\
\text { inconsistencies due to } \\
\text { differences in relations } \\
\text { between financial companies } \\
\text { and borrowers (different } \\
\text { capacity among farmers) }\end{array}$ & $\begin{array}{l}\text { Specificity of the target market of the } \\
\text { study, which suggests a possible model } \\
\text { with discriminant function for } \\
\text { agricultural purposes }\end{array}$ \\
\hline
\end{tabular}

Source: Prepared by the authors.

(b)

\begin{tabular}{cc}
\hline Criteria & Companies \\
\hline Initial sample & 54.017 \\
Companies that have at least one value for total assets. & 3.211 \\
Companies that have at least one Z'-Score & 1.561 \\
Companies that have a sequence of at least five continuous years for the Z'-Score and no breaks in the series & 622 \\
Final Sample & 622 \\
\hline
\end{tabular}

Source: Prepared by the authors, based on data from Capital IQ ${ }^{\circ}$. 
The synthesis procedure for the characterization of the sample is started by grouping the companies by country, then ordering these from the largest to the smallest number of companies before calculating the cumulative percentage. Figure 1 presents the sample information of the five countries with the largest number of companies that have failed. They represent more than $91 \%$ of the total, 568 of 622 . That does not mean that these countries have bigger problems with the survival of companies, but merely that they are countries which have companies that present data.

The second synthesis is done by grouping the companies by sectors, ordering from highest to lowest percentage (quantity) and calculating the percentage accumulated. The first five are: discretionary consumption (non-essential), information technology, industry and agriculture, financial, and health. They account for $84.72 \%$ of the total number of companies.

\section{Analysis and Discussion of Results}

The analysis and discussion of results are organized according to the order of hypotheses proposed. Hypothesis $\mathrm{H} 1$ inquires if the Z'-Score is valid for private companies and is performed by grouping the companies by $\mathrm{Z}$ '-Score class.

Some companies have only five years of the indicator throughout the series, but there are companies with values above this period, and the maximum identified is the Z'-Score value for a series of twenty-five years for the same company.

Then there are variations in the amount of $Z$ '-Score calculated for each company, and for the total of 622 companies over 29 years, it makes up 5345 firm-years results of the Altman bankruptcy score. Along the time trajectory,

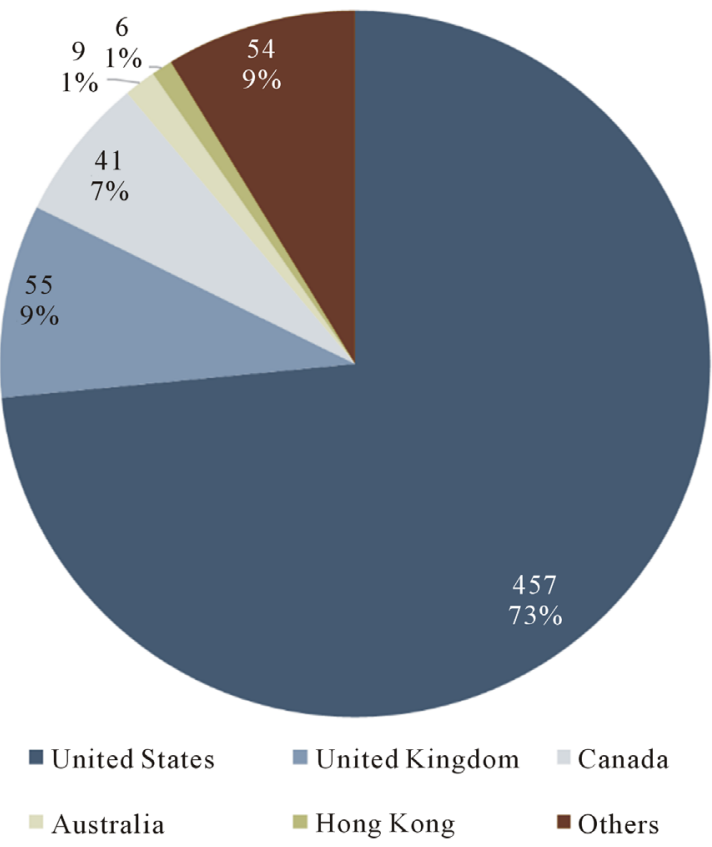

Countries

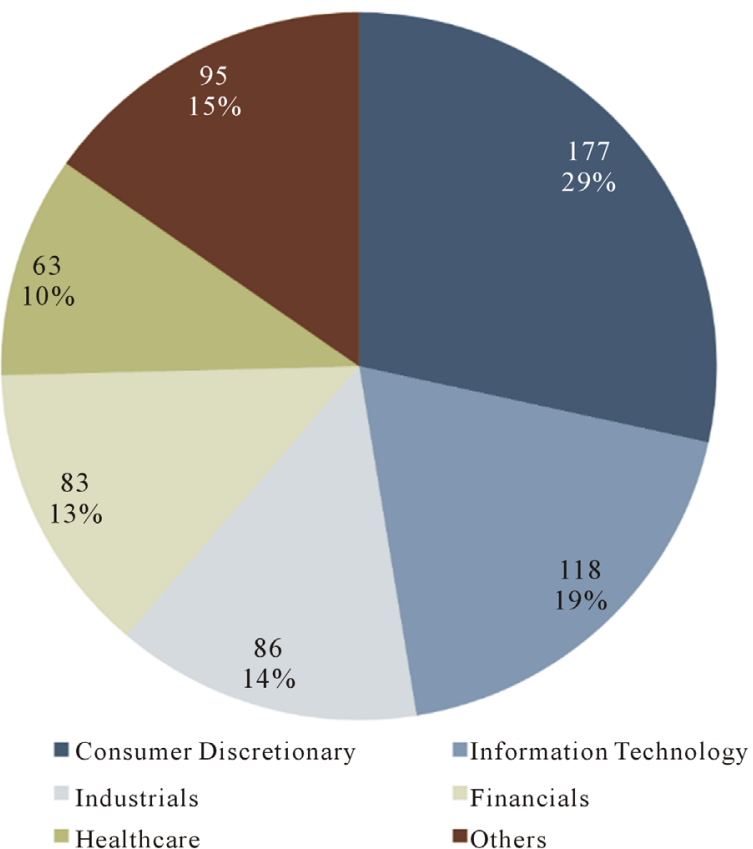

Sectors

Figure 1. Sample profile by country and by sector. Source: Prepared by the authors, based on data from Capital IQ ${ }^{\circledR}$. 
some companies may have achieved healthy Z'-Score results but signaled an adverse financial scenario a few years before bankruptcy. This is the scenario that guides the choice to observe the last five years in which there are data for the company before its bankruptcy.

Therefore, the definitive sample includes the 622 companies for the last five years of their activities, making 3110 firm-years Z'-Score calculations that are grouped into three classes: bankrupt, gray and non-bankrupt. This information is reported in Table 2. The precision column of the tables in this study shows the correctness and error values, given that the sample is from failed companies. The gray class is not considered in this analysis.

Table 3 presents Z'-Score results at the company level. As the analysis is temporal, distinct from the version conducted by [4], the analysis is divided into three perspectives.

In the first, correspond results to bankruptcy indicator for each of the last five years, with T-1 being the year immediately prior to the company's bankruptcy (no data) and T-5 being the fifth year preceding the end of business activity (for each of the 622 companies). The results suggest that how closer to the bankruptcy scenario (T-1), Altman model is more accurate, and it is better adjusted since the proportion of gray and non-bankrupt bankruptcy increases as bankruptcy get closer.

This context shows the importance of the temporal analysis in two aspects: a) companies that offer financial resources and have the practice of requesting temporal data may have greater precision in analytical capacity in terms of the bankruptcies of their clients; b) these same companies can reduce the margin of error to some extent when considering a longitudinal perspective, since they follow the trend of their customers.

Table 2. Z'-Score results by classification.

\begin{tabular}{cccc}
\hline Class & Number of Z'Score & Percentage & Accuracy \\
\hline Bankrupt & 1.599 & $51.41 \%$ & Hit \\
Gray & 905 & $29.10 \%$ & \\
Non-bankrupt & 606 & $19.49 \%$ & Error \\
Total & 3.110 & $100.00 \%$ &
\end{tabular}

Source: Prepared by the authors, based on data from Capital IQ ${ }^{\circledR}$.

Table 3. Z'-Score classes per year before company bankruptcy.

\begin{tabular}{ccccccc}
\hline Class & T-1 & T-2 & T-3 & T-4 & T-5 & Accuracy \\
\hline Bankrupt & $60.93 \%$ & $56.27 \%$ & $49.04 \%$ & $47.11 \%$ & $44.05 \%$ & Hit \\
Gray & $23.47 \%$ & $26.85 \%$ & $31.51 \%$ & $31.35 \%$ & $32.32 \%$ & \\
Non-bankrupt & $15.59 \%$ & $16.88 \%$ & $19.45 \%$ & $21.54 \%$ & $23.63 \%$ & Error \\
Total & $100 \%$ & $100.00 \%$ & $100.00 \%$ & $100.00 \%$ & $100.00 \%$ & \\
\hline
\end{tabular}

Source: Prepared by the authors, based on data from Capital IQ ${ }^{\circledR}$. 
The second analysis perspective, presented in Table 4, involves some more rigid Z'-Score analysis criteria. Over the five years prior to bankruptcy, the number of bankruptcy evidences is considered. In this most rigorous scenario, five bankruptcies (bankruptcy results) are counted before companies' bankruptcy.

From 622 companies in total, only $29.90 \%$ have continuous class of bankruptcy, that is, bankrupt classification in its five years before bankruptcy. For companies that pointed out four evidences, in four years there are signaling of bankruptcy, but in one of them the identified scenario was gray or non-bankruptcy. This situation should be viewed cautiously, since this different class of Z'-Score bankruptcy may have been identified in any of these five years under review by each company.

Identifying the result of gray or non-bankruptcy in any of the five years does not necessarily sign that the Altman model is inaccurate. For example, it is possible that a company has performed well financially, but in a specific period has had difficulties and ceased its activity. This period may have occurred only in the year preceding the breach, or two years earlier. However, the opposite situation may also exist. The Altman model can signal the year immediately preceding the break as non-bankruptcy (or gray), while the previous four years point to the result of bankruptcy. Therefore, identifying four, three, two, or even a single bankruptcy evidence does not bring so much information, while the extremes indicate that the model hits $(29.90 \%)$ and errs $(27.97 \%)$ in practically the same proportion.

This perspective is not satisfactory in terms of a temporal representation of the context of corporate bankruptcy. The amount of evidence of bankruptcy per company can generate a distortion, depending on the opposite position (non-bankruptcy). To circumvent this issue, it is proposed to calculate the arithmetic mean of the Z'-Score for each company in this data range of five years. The result, again, is classified in each of the indicator classes. The results are shown in Table 5 .

The result shows that the model could be still valid, but not robust, by correctly assigning only $53.38 \%$ bankruptcy condition of the data sample. The result

Table 4. Amount of evidence of bankruptcy by company.

\begin{tabular}{cccc}
\hline & Score signaling bankruptcy before the break & Percentage & Accuracy \\
\hline Five evidences & 186 & $29.90 \%$ & Hit \\
Four evidences & 71 & $11.41 \%$ & \\
Three evidences & 58 & $9.32 \%$ & \\
Two evidences & 75 & $12.06 \%$ & \\
One evidence & 55 & $8.84 \%$ & \\
Zero evidence & 174 & $27.97 \%$ & Error \\
Total & 622 & $100.00 \%$ & \\
\hline
\end{tabular}

Source: Prepared by the authors, based on data from Capital IQ ${ }^{\circledR}$. 
Table 5. Mean Z'-Score (five years) by companies and classification.

\begin{tabular}{cccc}
\hline Class & Companies & Percentage & Accuracy \\
\hline Bankrupt & 332 & $53.38 \%$ & Hit \\
Gray & 170 & $27.33 \%$ & \\
Non-bankrupt & 120 & $19.29 \%$ & Error \\
Total & 622 & $100.00 \%$ & \\
\hline
\end{tabular}

Source: Prepared by the authors, based on data from Capital IQ ${ }^{\circledR}$.

of gray companies is relevant, about a quarter of the sample, as well as of companies in non-bankruptcy, which corresponds to almost $20 \%$ of the set of companies. The adoption of the time criteria for this group of companies did not prove to be an indication of the strengthening of the bankruptcy indicator.

Comparing the results of the five-year average with the observed T-1 score, the one-year observation indicator in the year prior to the break indicated slightly better performance $(60.77 \%$ versus $53.38 \%)$. It also showed a better result in the non-bankruptcy condition $(15.59 \%$ in case $\mathrm{T}-1$, when in the five-year average this was $19.29 \%)$.

Therefore, inconsistencies were identified in the Altman method [4] in relation to the set of companies in this research, either in the temporal perspective or in the static perspective. This evidence converges with the findings of [10], and those of [11].

In this case, the temporal nature was not able to better explain the phenomenon of bankruptcy than examining a single point in time. This fact suggests that representative variations can occur within a year in terms of the company's financial performance, to bring about an adverse scenario that results in bankruptcy.

Many companies in the sample had a non-bankruptcy class but had a reversal of class one year before their bankruptcy. In these cases, the frequency of semiannual or quarterly data may yield more adequate results in this temporal issue.

The $\mathrm{H} 2$ hypothesis, which inquires if the Z'-Score is valid for companies from different countries, is tested by adopting this firm-year classification of $Z^{\prime}$-Score of three classes and through the analysis of two. The correctness and error results are deployed per country.

Table 6 shows a hit level approximately at $60 \%$ on average. In all cases where the sample per country is greater than 40 companies, the hit rate is around $40 \%$. These results do not support the claim that the Z'-Score is valid for companies from different countries, that is, it has no support to the possibility of being generalized to jurisdictions different from the United States, its country of creation. One possible explanation could be as [9] suggests that countries have distinct accounting regimes, especially the American and European models, which can generate asymmetries between both datasets, and interfere with the results obtained by the model through multiple discriminant analysis, since this is part 
Table 6. Precision of the Z'-Score by country.

\begin{tabular}{ccccc}
\hline Countries & Companies & Error & Gray & Hit \\
\hline United States & 457 & $14.44 \%$ & $21.01 \%$ & $64.55 \%$ \\
United Kingdom & 55 & $12.73 \%$ & $32.73 \%$ & $54.55 \%$ \\
Canada & 41 & $26.83 \%$ & $31.71 \%$ & $41.46 \%$ \\
Australia & 9 & $33.33 \%$ & $44.44 \%$ & $22.22 \%$ \\
Hong Kong & 6 & $0.00 \%$ & $50.00 \%$ & $50.00 \%$ \\
Others & 54 & $18.52 \%$ & $22.22 \%$ & $59.26 \%$ \\
\hline
\end{tabular}

Source: Prepared by the authors, based on data from Capital IQ.

of accounting and financial indicators.

Hypothesis $\mathrm{H} 3$ asks if the Z'-Score is valid for companies of different sectors. Adopting two classes, the results of correctness and error are deployed by sector, being valid for the period immediately before the break.

Table 7 shows a hit level only at $40 \%$ in all cases where the sample by sector is greater than 30 companies. This result do not support the claim that the Z'-Score model is valid for companies in different sectors. It has no potential to be generalized to other sectors.

It should be mentioned that the success rate is higher than $67 \%$ for the sectors of information technology, health, energy, materials, and telecommunications services. On the other hand, the non-essential consumption, essential consumption, and financial sectors had the lowest hit rates (below 50\%). Therefore, it is possible to observe a higher rate of adjustment for companies in the service sector, given the lower performance of the indicator for trade and industry.

The H4 hypothesis inquires if, based on the selection criteria of the sample that meet the factors simultaneity, minimum amount of years, and continuity of data for each company for the calculation, the Z'-Score may present some antecedent variable of crises of an economic and/or financial nature. In other words, the sample was constituted considering all the accounting factors required to estimate the Z'-Score and, from this premise, the percentage change of bankruptcy of companies before and after some crisis-triggering period is verified.

The data set in Table 8 shows the rate of growth of corporate bankruptcy in the years before the outbreak of some economic/financial crises. There was a considerable increase in the number of corporate failures before the crises in Brazil (1999) and in the United States (2000 and 2008).

These results indicate that, possibly, a good part of the financial performance of the companies could be linked to the economic growth of the developed and emerging countries, or even to the American economy, and that financial stability, reduction in the economic trajectory, and even the flow of business was adversely affected, even if they originated in different countries. This scenario could explain the increase in bankruptcies, since it is a strong and adverse shock for entrepreneurs. 
Table 7. Precision of the Z'-Score by sector.

\begin{tabular}{ccccc}
\hline Sector & Companies & Error & Gray & Hit \\
\hline Consumer Discretionary & 177 & $13.56 \%$ & $38.42 \%$ & $48.02 \%$ \\
Information Technology & 118 & $8.47 \%$ & $16.95 \%$ & $74.58 \%$ \\
Industrials & 86 & $10.47 \%$ & $25.58 \%$ & $63.95 \%$ \\
Financials & 83 & $39.76 \%$ & $16.87 \%$ & $43.37 \%$ \\
Healthcare & 63 & $4.76 \%$ & $6.35 \%$ & $88.89 \%$ \\
Materials & 31 & $6.45 \%$ & $25.81 \%$ & $67.74 \%$ \\
Consumer Staples & 27 & $37.04 \%$ & $25.93 \%$ & $37.04 \%$ \\
Telecommunication Services & 23 & $17.39 \%$ & $8.70 \%$ & $73.91 \%$ \\
Energy & 14 & $14.29 \%$ & $7.14 \%$ & $78.57 \%$ \\
\hline
\end{tabular}

Source: Prepared by the authors, based on data from Capital IQ.

Table 8. Economic/financial crises and changes in corporate bankruptcies.

\begin{tabular}{ccc}
\hline Country-Year of the crisis & $\begin{array}{c}\text { Change in bankruptcies } \\
\text { between the year before and } \\
\text { the year of the crisis }\end{array}$ & $\begin{array}{c}\text { Change in bankruptcies between } \\
\text { the year of the crisis and } \\
\text { the year after }\end{array}$ \\
\hline $\begin{array}{c}\text { Brazil-1999 } \\
\text { Internet bubble } \\
\text { (EUA)-2000 }\end{array}$ & $142.86 \%$ & $205.88 \%$ \\
Subprime (EUA)-2008 & $205.88 \%$ & $23.08 \%$ \\
& $16.28 \%$ & $-2.00 \%$ \\
\hline
\end{tabular}

Source: Prepared by the authors, based on data from Capital $\mathrm{IQ}^{\circledR}$.

Similarly, it is noticeable that in the year after these crisis, many companies still went bankrupt, possibly due to the optimistic expectation of the entrepreneurs or the restrictive measures adopted by the governments that did not have a positive effect in the short term, to avoid a more representative fall in companies.

In the case of the United States (US) the variation between the year before the crisis cited is that it stands out. For the Internet bubble, it is possible to observe a variation of $205.88 \%$ a continuation of business downturn, with even more company failures after the crisis began, but with a decreasing rate that reached $23.08 \%$. In the Subprime Crisis, there was a growth of bankruptcies between 2007 and 2008, but the peak of corporate downturn occurred just in the year when the crisis was triggered, with almost the same amount of companies leaving the market in 2009.

Selected financial crises indicated a certain decrease in the variation in the number of bankruptcies between the year of the crisis and the year immediately preceding. This factor could be attributed to the growth trajectory of bankruptcies in years before the crisis, that is, the adverse shock is smoothed over time, up to the event. Therefore, companies broke down at a more pronounced pace before the crisis, acting as a signal that the main event was yet to come. It is 
worth mentioning that the epicenter of the crisis occurred in the United States, whose economy has a greater dynamism, and where government actions were representative of efforts to immediately contain the adverse effects on the economy, including in the recovery of companies and the re-heating of economic activity. In this context, the use of the Z'-Score criterion to define the sample could be relevant to try to help identify economic and/or financial crises as antecedent variables.

Hypothesis H5, from the selected sample with the criteria of the Z'-Score, asks if crises of an economic and/or financial nature also affect the target sectors of the study.

For this demonstration, the companies are grouped by year of their respective bankruptcies and by sector. The year of bankruptcy is understood as the first year in which the accounting information is no longer available for all the indicators necessary for the calculation of the Z'-Score.

Because of selected economic and financial crises, especially speculative in the period of analysis, it is particularly important to identify the segment that signaled the largest volume of corporate failures, since some may be more vulnerable to financial market crises, while others are more affected by events in the real economy.

In Figure 2 and Figure 3, the abscissa contains the data of the sample years, and in the ordinate are the quantities of companies that failed that year. Indicators by sector show a greater number of bankruptcies for the segments: non-essential consumption (discretionary), information technology, industrial products, financial, health, materials, consumption of essential goods, telecommunications

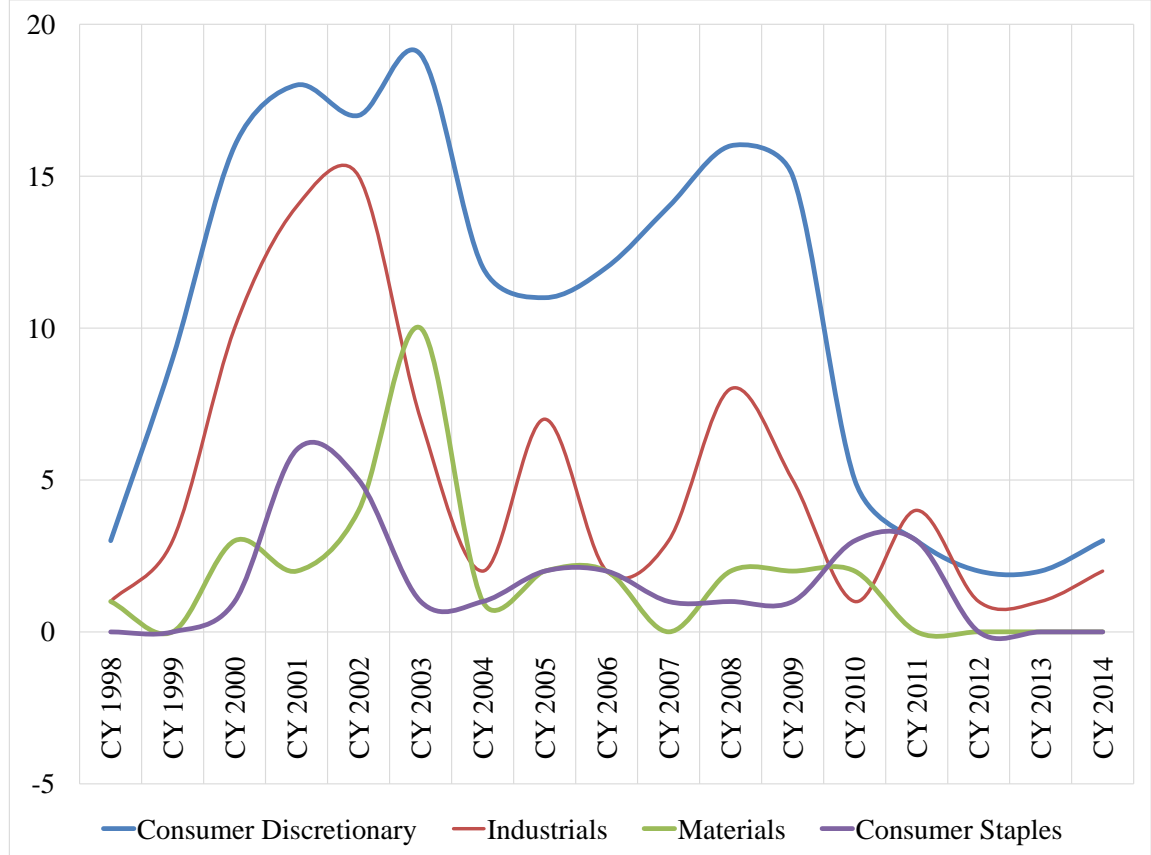

Figure 2. Number of companies broken down by year by sector (a). Source: Prepared by the authors, based on data from Capital IQ ${ }^{\circledR}$. 


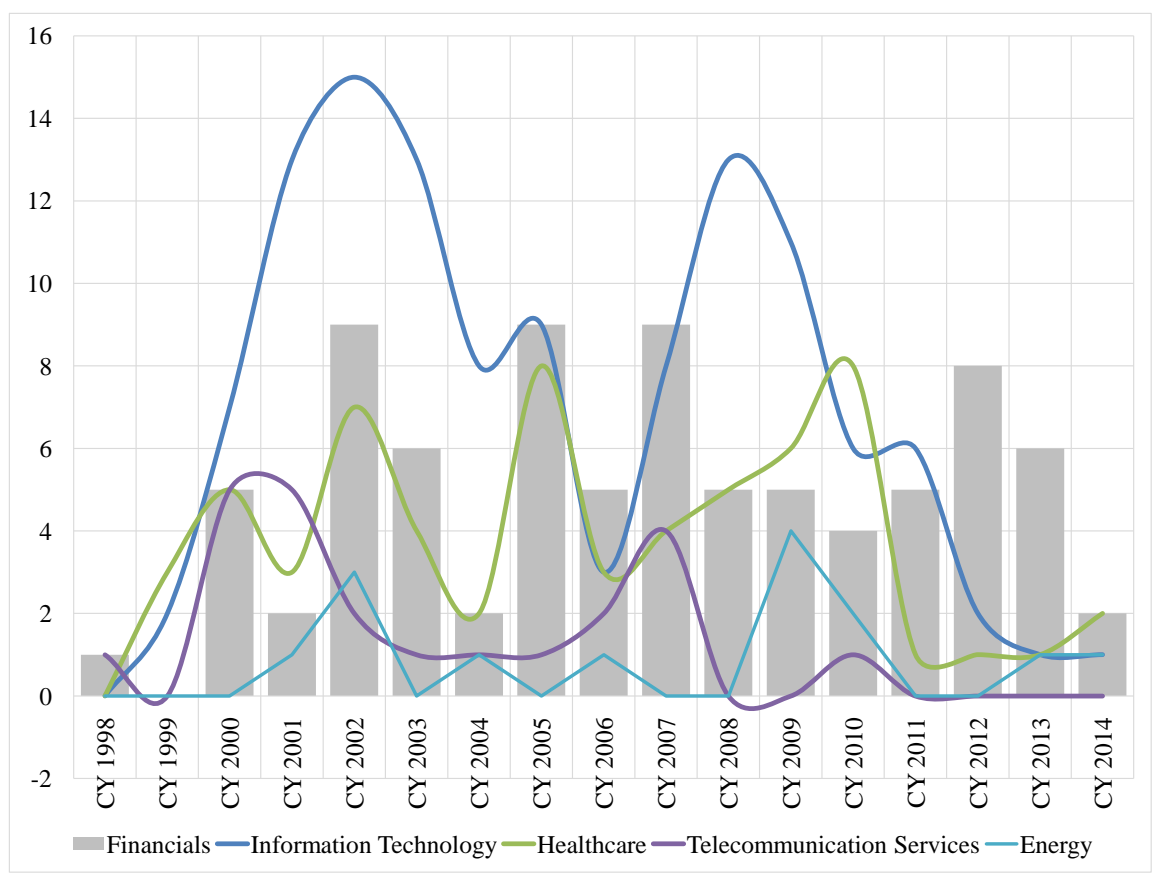

Figure 3. Number of companies broken down by year by sector (b). Source: Prepared by the authors, based on data from Capital IQ ${ }^{\circledR}$.

services, and energy, respectively.

It should be noted that the number of failures in the industrial and discretionary sectors has an upward trend a few years before the crises of 2000 and 2008. In this case, the peak of bankruptcy of these segments occurs in the actual year of the crisis or in the immediately subsequent period.

On the other hand, the essential goods consumption sector points to a slightly upward trend in the period up to the year of the internet bubble crisis, with a peak just in that year. Already in later years, there is practically no representative variation in the series. This fact can be explained by the importance of the product offered by these companies having an inelastic demand, such that it is more persistent during periods of financial difficulty in the economy. The credit constraint-or even the increase in the interest rates of the contracts-could explain the periods of greater oscillation. This behavior indicates that this industry has specific characteristics, and little helps the method in identifying the crisis context.

The materials sector has an opposite behavior to the consumption of essential goods. The data indicate that the period immediately prior to the 2000 and 2008 crises did not suggest a scenario of a large volume of bankruptcies, with the peak identified only in the year 2003. It is possible that the borrowing and medium-term financing affected companies more severely immediately after this crisis. In the rest of the series, there are no representative oscillations.

The health segment points to oscillations throughout the series with a growth trajectory until 2010, after indicating a sharp fall. The years of crisis do not denote a scenario in which the peak is observed a few years later. This result sug- 
gests that health is considered as one of the most important factors for consumers, so it reflects on the financial performance of companies.

Employment and income can also explain this scenario, as companies directly affected by institutional measures in the country and the ability to pay their customers may interfere with financial performance. The break has been a smoothed process over time, rather than an immediate shock during the crisis, as observed for the information technology industry. An analogous result can be conducted for the energy segment, although it shows an absence of bankruptcy data for some years of the series given the selected sample.

The financial sector in relation to the financial crises (Internet bubble and Subprime) presents as a dynamic a sign of pre-crisis shocks, since there is a great fall of companies in the period before the crisis year. This context may be because some companies in other segments are no longer able to repay loans and financing, as well as consumers, so that this affects the optimum performance of these companies.

The information technology sector presents a movement very similar to that of discretionary consumption, since there is a strong pattern towards the growth of bankruptcies before the crisis is triggered, but it persists with growth until the respective year. This context implies that imminent signs of a crisis are felt immediately by companies in this sector that are more difficult to recover from in markets with financial instability.

In the context of this study, hypothesis $\mathrm{H} 5$, which states that economic and/or financial crises also affect the target sectors of the study, is weakened under the Z'-Score perspective, which may be particularly important for the performance of decision makers in order to conduct measures to stimulate economic activity or even mitigate the bankruptcy of companies with a view to preserving a more favorable economic environment for both the real economy and the financial point of view.

Therefore, it is possible to observe that even in a different economic context, with a more representative and segmented sample in more sectors and other economies, the Z'-Score model, containing multivariate data analysis of privately-held companies, needs further studies to infer if this is a valid instrument for the analysis of sector bankruptcy. However, the findings for the selected sample indicate, for now, that the model has only limited ability to predict company bankruptcy, since two-thirds of the sample of companies that effectively failed were correctly diagnosed with a bankruptcy scenario.

When analyzing the factors and their weights, it is possible to characterize the emphasis that the Z'-Score model has (multivariate discriminant model). Taking a temporal perspective as the basis, it is possible to classify these into factors more related to liquidity and more related to profitability. Each factor can be correctly interpreted as impacting the short and long term. In this analysis, it is assumed that a lack of profitability, for the short term, does not lead the company to bankruptcy, while a lack of liquidity does. Factors $X_{1}, X_{2}$ and $X_{4}$ are classified 
Table 9. Analysis of the proportion of the weights of the Z'-Score factors.

\begin{tabular}{cccccc}
\hline Factor & $X_{1}$ & $X_{2}$ & $X_{3}$ & $X_{4}$ & $X_{5}$ \\
\hline Weight & 0.717 & 0.08 & 3.107 & 0.42 & 0.998 \\
Proportion & 8.47 & 1.00 & 36.68 & 4.96 & 11.78 \\
\hline
\end{tabular}

Source: Prepared by the authors, based on data from Capital IQ ${ }^{\star}$.

as more liquidity-related, factor $X_{3}$ to profitability, and $X_{5}$ cannot be classified since it can be in both categories.

Factor $X_{1}$ connotes the extent to which the operational aspects (working capital) are generators or cash takers versus the asset applications. The $X_{2}$ factor refers to the dividend policy, which, in the short term, impacts on the immediate cash level. Factor $X_{4}$ is related to leverage. This indebtedness is a liability that periodically impacts on the cash level in the short term. Factor $X_{3}$ is an indicator of profitability since it is measuring the operational return, i.e., it regards the long term. Factor $X_{5}$ is associated with asset turnover, where the level of sales substantially impacts on the available cash level. Discrimination in the form of receipt is not explicitly present, which compromises the liquidity analysis.

By observing the weights given to the factors, it is possible to do a proportionality analysis, taking the lowest weight $\left(X_{2}\right)$ and dividing all the weights by it. The result is shown in Table 9.

Short-term factors $\left(X_{1}, X_{2}\right.$ and $\left.X_{4}\right)$ that are directly linked to liquidity have weights that are significantly lower than the factor linked to profitability, $X_{3}$, which is more than 36 times greater than the weight of the factor linked to the dividend policy. Even factor $X_{5}$, which can be tied from the short to the long term, has a weight of less than a third of factor $X_{3}$. Therefore, it is possible to infer that the model privileges the long-term factor over the short-term factor. This may also be indicative of improvements in the model in relation to the forecast of insolvency.

There is also the possibility that other factors not observed in the Altman multivariate model are important in identifying the risk of corporate bankruptcy. Intangible assets, information asymmetry, indicators of performance, risk, and efficiency, as well as the growth trajectory can help in understanding the phenomenon.

\section{Conclusions}

In testing the accuracy of the Altman bankruptcy forecasting model for a wide "out of business status" private companies sample that failed between 1985 and 2013, it can be seen that the 1993 model presented predictive power around $60 \%$. The financial ratios used in the model calculations and the Z'-Score was not supported that provides useful information on the chance of bankruptcy for the privately-held companies in the sample.

The results do not support that the Z'-Score has the potential to be generalized to jurisdictions different from the United States, its country of creation. Hig- 
hlighting there may be distinctions between the models of accounting regimes between countries. It has also been shown to not be applicable to different industrial sectors, including financial ones. This fact does not support the robustness of the methodology proposed by Altman.

The presence of limitations on the results obtained, the method needs more investigations to assure if it acts as an instrument of analysis by both credit and financial companies, the managers of the companies themselves, and also in the strategy of public policies that can reflect directly on the activity of economic sectors.

Therefore, it is still open if this model may contribute to the understanding of an instrument prior to economic and/or financial crises, since it signals shortand medium-term trajectories of corporate bankruptcy.

It is important to continue these studies with the inclusion of other variables that can better understand the phenomenon, since a third of the sample indicated a non-bankruptcy scenario or was without result (gray), or else, the model itself may need revision before the distribution of the composition of weights for each indicator.

\section{References}

[1] Bressan, V.G.F., Braga, M.J. and Bressar, A.A. (2004) Análise de risco de insolvência pelo modelo de Cox: Uma aplicação prática. Revista administração de empresas, v. 44, número espacial, São Paulo.

[2] Altman, E.I. (1968) Financial Ratios, Discriminant Analysis and the Prediction of Corporate Bankruptcy. Journal of Finance, 23, 589-609. https://doi.org/10.1111/j.1540-6261.1968.tb00843.x

[3] Caouette, J.B., Altman, E.I., Narayanan, P. and Nimmo, R. (2008) Managing Credit Risk: The Great Challenge for the Global Financial Markets. 2nd Edition, John Wiley \& Sons, New York. https://doi.org/10.1002/9781118266236

[4] Altman, E.I. (1993) Corporate Financial Distress and Bankruptcy. 2nd Edition, John Wiley \& Sons, New York.

[5] Altman, E.I. and Hotchkiss, E. (2005) Corporate Financial Distress and Bankruptcy: Predict and Avoid Bankruptcy, Analyze and Invest in Distressed Debt. 3rd Edition, John Wiley \& Sons, New York. https://doi.org/10.1002/9781118267806

[6] Muminović, S. (2013) Revaluation and Altman's Z-Score-The Case of the Serbian Capital Market. International Journal of Finance and Accounting, 2, 13-18.

[7] Pok, W.C. (2012) Analysis of Syariah Quantitative Screening Norms among Malaysia Syariah-Compliant Stocks. Investment Management and Financial Innovations, 9, Issue 2 .

[8] Mantziaris, S.Z. (2015) Bankruptcy Prediction Models: An Empirical Analysis of Altman's Z-Score Model in Forty Greek Companies in the Period of Economic Recession. Dissertation, School of Business Administration, Department of Accounting and Finance, University of Macedonia.

[9] El Khoury, E.; Al Beaïno, R. (2014) Classifying Manufacturing Firms in Lebanon: An Application of Altman's Model. Procedia-Social and Behavioral Sciences, 109, 11-18. https://doi.org/10.1016/j.sbspro.2013.12.413

[10] Muminović, S., Pavlović, V. and Cvijanović, J.M. (2011) Predictive Ability of Vari- 
ous Bankruptcy Prediction z-Score Models for Serbian Publicly Listed Companies. Economics Institute a.d. Beograd, Industrial, v.39, issue 3, pp. 1-12.

[11] Zhang, T. and Ellinger, P.N. (2006) Credit Risk and Financial Performance Assessment of Illinois Farmers: A Comparison of Approaches with Farm Accounting Data. American Agricultural Economics Association Annual Meeting, Long Beach, CA, 23-26 July 2006. 